\title{
The concept of space in Classic Mayan
}

\author{
Agnieszka Hamann
}

\begin{abstract}
The ancient Maya civilization left us a significant corpus of glyphic inscriptions, a large portion of which consists of historical records, meticulously dating events and time elapsed between them - births, accessions and deaths of rulers, wars, ceremonies, visits and family relationships between royal dynasties, etc. (see Martin and Grube 2008). Time being such a prominent topic, the texts contain a number of time-related terms, including (1) event-based expressions ( $t$ i ik' $k$ 'in 'at black day / at dusk / at night'; i pas 'then at dawn'; si[h]yajiiy '(X years) after s/he was born'), (2) conceptualizations which are potentially and likely spatial in nature as they appear both in locative expressions and temporal adverbials (preposition ti 'in/on/at/with/ as; the verb uht 'to happen' and deictic verb hul 'to arrive'; tu paat + date 'on the back of / after), and finally, (3) non-spatial metaphorical conceptualizations, such as reification and personification of the units of time. Sweetser and Gaby $(2017,626)$ notice that "crosslinguistically, the single primary historical source for temporal vocabulary is spatial vocabulary" and it is an overwhelming tendency observed in numerous languages around the world. Levinson and Wilkins $(2006 c, 6)$ also pose an interesting question how much spatial information is coded in language and how much is inferred from context and our knowledge of the world around us. The concept of space being so basic and significant, surprisingly little has been published on how space was conceptualized in Maya texts of the Classic Period (250-950 CE). Thus, this paper investigates how the domain of space is coded in Classic Mayan, a grapholect recorded in Maya glyphic inscriptions, how the language expresses relationships of containment, contiguity and adjacency, the manner and path of motion events, as well as available frames of reference to locate objects which are separated in space.

Keywords: Classic Mayan, the concept of space, semantic topological description, verbs of motion, frames of reference
\end{abstract}

\section{Resumen}

EL CONCEPTO DE ESPACIO EN EL CLÁSICO MAYA

La antigua civilización maya nos dejó un importante corpus de inscripciones glificas, una gran parte de las cuales consiste en registros históricos, que datan meticulosamente los eventos y el tiempo transcurrido entre ellos: nacimientos, accesiones y muertes de gobernantes, guerras, ceremonias, visitas y relaciones familiares entre la realeza. dinastías, etc. (véase Martin y Grube 2008). Siendo el tiempo un tema tan destacado, los textos contienen una serie de términos relacionados con el tiempo, que incluyen (1) expresiones basadas en eventos ( $t i$ ik' k'in 'en el día negro / al anochecer / en la noche'; i pas 'luego en amanecer '; si[h]yajiiy '( $X$ años) después de su nacimiento'), (2) conceptualizaciones que son potencial-

Agnieszka Hamann • University of Warsaw, email: ahamann@uw.edu.pl, 
mente y probablemente de naturaleza espacial, ya que aparecen tanto en expresiones locativas como en adverbiales temporales (preposición ti 'en / con / como'; el verbo uht 'suceder' y el verbo deíctico hul 'llegar'; tu paat + date 'en la parte posterior de / después), y finalmente, (3) conceptualizaciones metafóricas no espaciales, tales como concretización y personificación de las unidades de tiempo. Sweetser y Gaby $(2017,626)$ notan que "de manera interlingüistica, la única fuente histórica primaria para el vocabulario temporal es el vocabulario espacial" y es una tendencia abrumadora observada en numerosos idiomas en todo el mundo. Levinson y Wilkins $(2006$ c, 6) también plantean una pregunta interesante sobre cuánta información espacial se codifica en el lenguaje y cuánta se infiere del contexto y nuestro conocimiento del mundo que nos rodea. Siendo el concepto de espacio tan básico y significativo, sorprendentemente poco se ha publicado sobre cómo se conceptualizó el espacio en los textos mayas del Período Clásico (250-950 d.C.). Por lo tanto, este artículo investiga cómo se codifica el dominio del espacio en el maya clásico, un grafolecto registrado en las inscripciones glíficas mayas, cómo el lenguaje expresa relaciones de contención, contigüidad y adyacencia, la manera y la trayectoria de los eventos de movimiento, así como los marcos disponibles de referencia para localizar objetos que están separados en el espacio.

Palabras clave: maya clásico, concepto de espacio, descripción topológica semántica, verbos de movimiento, marcos de referencia.

\section{Introduction}

The concept of space is among the most basic concepts that humans start acquiring from the first weeks of their lives. By observing and interacting with the environment, we develop relatively abstract and schematic representations called "image schemas", such as Up-Down, Near-Far, In-Out, Source-Path-Goal, which later form the basis of our thinking and lexicon to talk about spatial relations and motion through space (Evans 2007, 106-8; see Figure 1 below). Thus, acquiring image schemas facilitates developing the concept of space and orientation in the physical environment (a mountain peak, the bottom of the pool, she rose to leave). Finally, the more basic and physical concept of space may be applied to think and talk about something more abstract, for example social relations (the peak of her career, the bottom of the hierarchy, she rose to the top - illustrating the conceptual metaphor SOCIAL POSITION IS VERTICAL ORIENTATION).
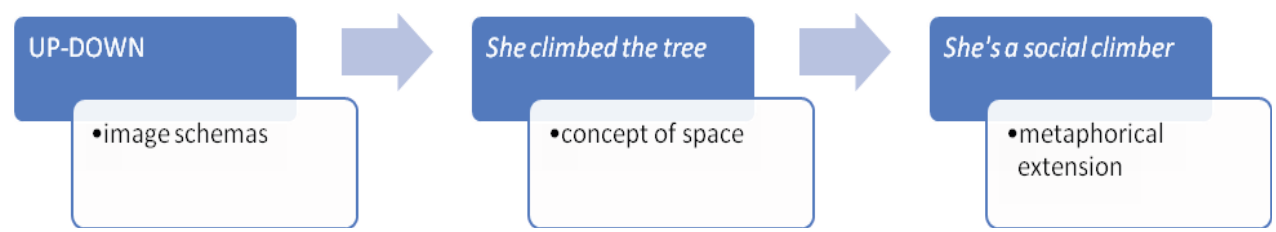

Figure 1: How image schemas provide basis for the development of the concept of space, which then, in turn, serves as the source domain for the metaphorical mapping into the target domain of social relations

Thus, all languages have varied resources to conceptualize (think and talk about) space, and while some of the models seem to be cross-culturally stable (nearuniversal), others are highly culture-specific (Heine 1997, 35-36, 11-12). Levinson and Wilkins (2006a, 3) propose to base crosslinguistic comparisons on three aspects of the domain of space, namely within the subdomain of stasis (static scenes) - 
topology and frames of reference, and within the subdomain of kinesis (dynamic scenes) - motion (see Figure 2).

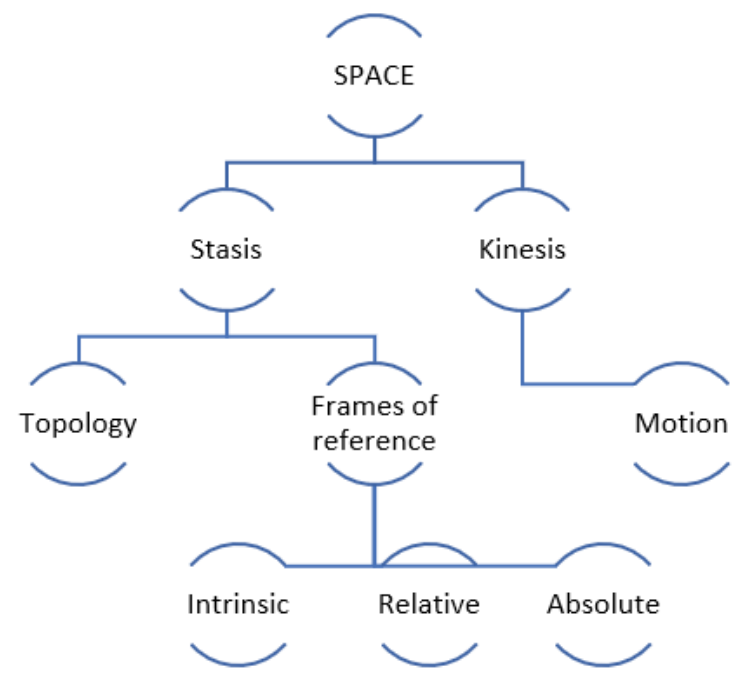

Figure 2: Conceptual subdivisions of the spatial domain (based on S. C. Levinson and Wilkins 2006c, 3; Figure 1.1)

\section{Topological description}

The topological description is concerned with typical replies to Where-questions (Where is $X$ ?, where $\mathrm{X}$ is the figure - the object to be located, and the reply provides the ground - the object(s) in relation to which it is to be located), which allows for the identification of a basic locative construction (BLC), that is how the language describes situations where figure and ground are in contiguity or close proximity (S. C. Levinson and Wilkins 2006b, 514). For example in English, the BLC consists of a noun phrase identifying the figure, the verb to be and a prepositional phrase identifying the ground (S. C. Levinson and Wilkins 2006c, 15): The cat is in the box (the relation of containment). Some languages have no verb to be and use nominal predication instead (e.g. Russian in present tense: Папа дома 'Dad [is] at home' - no verb, no preposition), other languages use positional verbs (e.g. Classic Mayan, see examples 9, 17-20) and positional particles (e.g. Tzeltal, see examples 50, 54-56).

\section{Frames of reference}

On the other hand, frames of reference (FoR) locate the figure with respect to a ground when the two are separated in space (S. C. Levinson and Wilkins 2006b, 541), e.g. The cat is in front of the box. Levinson and Wilkins propose 3 basic frames of reference (see Figure 3). 


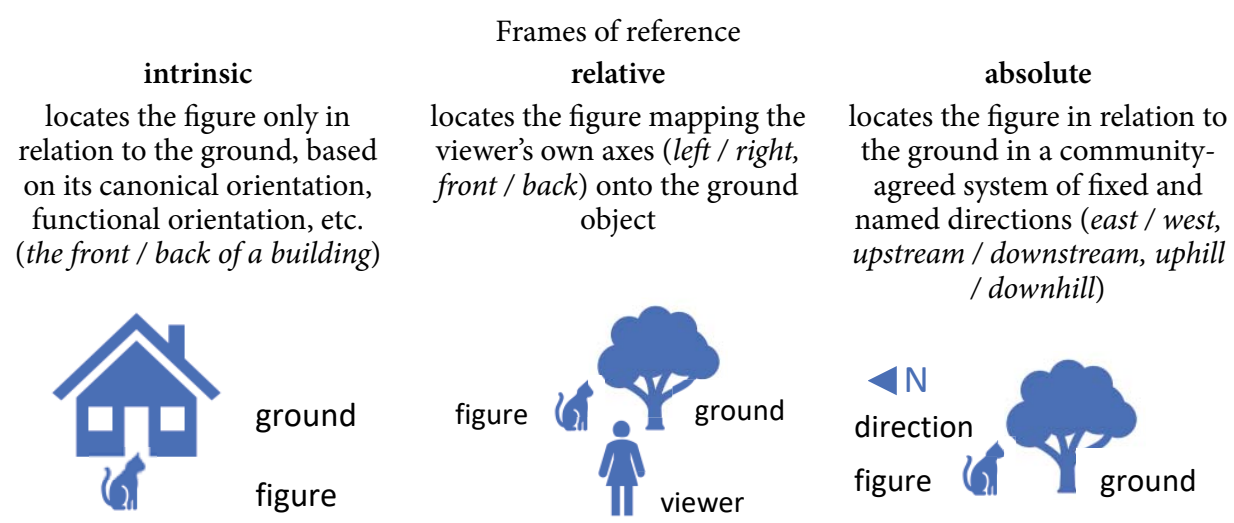

The cat is in front of the house

The cat is to the left of the tree
The cat is north of the tree

Figure 3: The classification of reference frames (S. Levinson 2003; S. C. Levinson and Wilkins 2006a, 20-21; 2006b, 541-42)

Spatial vocabulary tends to be derived from several source domains (Heine 1997, 57; Figure 4 below). Terms used to talk about deictic orientation are mainly speaker-deictic (Up, Down, Front, BACK, Left, Right in relation to the speaker) and may be based on the domains of body parts or landmarks, but never on terms for winds or the sun. In the landmark orientation model, reference points are typically rooted in the physical environment and use environmental landmarks, such as the local river, mountain or the sea, to describe locations, and they may be derived from landmarks or from terms for describing deictic orientation (e.g. away from the river, facing the mountain, downstream). Finally, cardinal orientation is defined in terms of fixed reference points (e.g. NoRTh, South) independently of the physical configuration of the communicative event; those terms tend to be derived not from body parts, but rather landmarks, the sun, winds or the domain of deictic orientation. Thus, there is a great deal of variation in the conceptualization and coding of the spatial domain across languages (S. C. Levinson and Wilkins 2006b, 512-13).

Figure 4: Main sources for spatial orientation (based on Heine 1997, 57, Table 3-9)

Main source domains

Body parts

Landmarks

Sun

Wind

Deictic orientation
Target domains

Deictic orientation

Landmark orientation

Cardinal orientation 


\section{Motion description}

The description of motion involves such aspects as semantic packaging of the verb and other linguistic resources which cooperate in a clause to describe the motion event, in particular how the notions of path and manner of motion are coded, how (and if) the source and goal are expressed (S. C. Levinson and Wilkins $2006 \mathrm{~b}, 527)$. Talmy $(1985 ; 2000)$ proposed the main opposition between verbframed and satellite-framed languages, where the defining factor is how the path is coded: the former conflate predication and path in the verb, while the latter conflate predication and manner in the verb, while path is expressed by another part of the clause (see Figure 5).

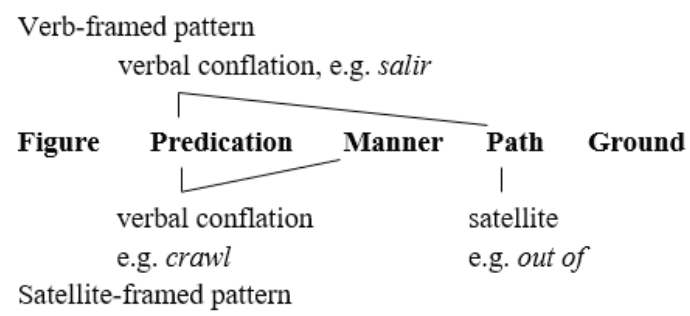

Figure 5: Talmy's (1985) typology of path encoding (based on Levinson and Wilkins 2006b: 18, Figure 1.6)

Levinson and Wilkins $(2006 \mathrm{~b}, 527)$ conclude that, since majority of languages that have been researched so far are verb-framed (with the exception of English and Dutch), thus "the Germanic satellite-framed pattern may be very restricted typologically". On the other hand, assigning a definitive pattern is really problematic for some languages because of the various ways they conceptualize motion (e.g. Tzeltal, see Brown 2006; and Yukatek, see Bohnemeyer and Stolz 2006).

\section{Classic Mayan}

Classic Mayan is the language attested in ancient Maya glyphic writing, in use from c. $300 \mathrm{BC}$ to after the European conquest, with the extant corpus of several thousand longer and shorter texts found on stone monuments, portable objects and in fragments of four surviving books (Law and Stuart 2017, 128). The corpus is thematically restricted to mainly historical and religious texts with a surprising uniformity of the script over numerous Maya kingdoms and over a long stretch of time, which suggests it was a grapholect - a written prestige language used along spoken vernaculars (ibid. 128, 133). 


\section{Topological description}

The topological description is concerned with static relations of containment, contiguity and immediate adjacency, which in English, e.g., are mainly expressed by prepositions: the child is in the room / on the chair / at school. The figure (the child) is located in relation to the ground (room/chair/school) and the various prepositions specify the kind of spatial relationship between the two (in - containment, on - support and contact, at - co-location conceptualized as a point (see Tyler and Evans 2007)).

\section{Prepositions}

In Classic Mayan there are only two prepositions, semantically neutral and functionally versatile $t i \sim t a$ for static locations and possibly the preposition tahn 'within, in the middle' (Kettunen \& Helmke 2019: 116), "which appears to be a grammaticalized reduction of the relational noun $u$-tahn 'its chest" and "generally appears in locative expressions referring to interior spaces, such as caves" (Law and Stuart 2017, 161), thus it may code the proper containment relation. Terms for body parts are cross-linguistically the most common source model for expressions of spatial orientation, and what is more, the diachronic development of such expressions follows from body-part through relational concept to spatial reference point (Heine 1997, 38-39). Thus, in case of this lexical item, it would be an extension from tahn 'chest' as a body part, to a relational noun $u$-tahn, and to purely locative tahn(il) exemplified in (1-4). Brown $(2006,244-45)$ and Bohnemeyer and Stolz $(2006,287)$ notice the same phenomenon in two modern Mayan languages, Tenejapan Tzeltal and Yukatek, where relational nouns and locative constructions became grammaticalized, some of them to such an extent that possessive prefix became optional.

(1) uht-i-iy-ø tahn-"3.stones"

happen-INTR-PST-3SA chest-PLACENAME

'it happened at Seibal' (Seibal Tablet)

(2) uht-i-iy-ø

tahn-ch'e'n Lakam $\mathrm{Ha}^{\prime}$

happen-INTR-PST-3SA chest-cave PLACENAME

'it happened at the cave / town (at / of) Lakam Ha” (Palenque Temple XIX platform south side)

(3) pat-waan- $\varnothing$

tahn-che'n mutul

form-POSIT-3SA

chest-cave PLACENAME

'it is formed / built at the cave / town (at) Tikal (Tikal Temple 1 Lintel 3)

(4) u-baaj-ø ti-cham tahn-il tiloom sajal

3E-image-3SA PREP-take chest-ABST PERSONAL.NAME

'it (is) his image at taking in front of Tiloom Sajal (La Pasadita Lintel 2) 
Thus, tahn clearly is the head of a locative expression, however, its interpretation as 'within', entailing the concept of proper containment, does not seem to be so obvious. It fits well example (1) and is likely for examples (2) and (3), but it does not work for example (4) where the ground is a person, therefore the figure cannot be contained in the ground. The context strongly points to the relation of contiguity or adjacency, especially because the accompanying image (see Figure 6) depicts two people facing each other - on the left Yaxchilan king Yaxuun Bahl-
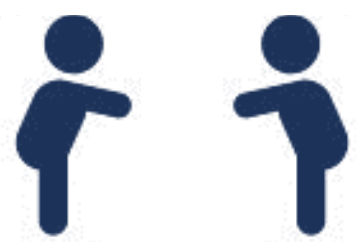

Figure 6: Schematic representation of the scene in example (4) the king on the left performing an action tahnil 'in front of' his subordinate lord am performing a ceremony, on the right assisting him is Tiloom Sajal, a subordinate lord from La Pasadita, mentioned in example (4). This is why for examples (1-3) featuring the form tahn, I chose the translation 'at' (analogously to $t i$ ), which in English does not precisely specify the kind of spatial relationship between the figure and ground, and for example (4) with tahnil, I chose 'in front of' based on the social context and accompanying image. The interpretation of Classic Mayan tahn(il) as 'in front of' would be consistent with modern Yukatek cognate táan(il) (see example (5) and Figure 7).

$$
\text { táan-il yàan } \quad \text { ti }
$$

front-REL EXIST(B.3.SG) LOC

'he is in front of it (the tree)' (Bohnemeyer and Stolz 2006, 302)

Figure 7: Some locative expressions derived from body-part terms in modern Mayan languages

Yukatek Maya (Heine 1997, 37 based on Goldap 1992:613; Stolz 1994: 61)

Body-part term

pàach 'back'

táan 'front'

ich 'eye'

Tzeltal (Brown 2006, 241-45)

Body-part term

$\begin{array}{ll}\text { pat } & \text { 'back } \\ j o l & \text { 'head } \\ t i & \text { 'mouth, lips' } \\ x u j k & \text { 'side, corner' }\end{array}$

Locative marker

pàach(il) 'behind'

táan(il) 'in front (of)'

ich-il 'inside'

ich 'in'

Locative marker

ta s-pat 'at its back'

ta s-jol witz 'on the top of the mountain'

ta $s$-ti'(il) 'at its mouth/edge'

ta s-xujks-ti'il

'in the corner at the edge' [of an envelope]

The all-purpose preposition $t i$ / $t a$ seems to have two stylistic variants: in 3 Post-Classic Maya codices (books), $t a$ and $t i$ are used interchangeably, perhaps even as equivalent or synonymous prepositions (Lopez 2012: 26, 44, 61, 138), althought 
variant $t a$ seems to be more archaic and more frequent until the Colonial Period when $t i$ becomes more prevalent (ibid. 147). Bricker and Orie (2014: 197-200) conclude that such $\mathrm{a} / \mathrm{i}$ alternation of glyphic spellings points to them being the representation of pronunciation of to ( $t+$ shwa), a hypothesis strongly corroborated by earlier work on geographical distribution of the variants by Macri (1991:271). Generally, preposition $t i / t a$ is, first of all, used with locative expressions (examples 6-8), but also to talk about placement in states (example 9, conceptual metaphor STATES ARE LOCATIONS), and in temporal expressions (example 10, conceptual metaphor TIME IS SPACE), as well as with instrumental and recipient/benefactive (Law and Stuart 2017, 161-62).

(6) t-u-kab-chen usijwitz'

PREP-3E-earth-cave PLACE.NAME

'in the town of Usij Witz' (Bonampak Sculptured stone 1)

(7) i uht-i-ø lakam ha' chan cheen $\boldsymbol{t}$-u cheen

then happen-INTR-3SA PLACE.NAME sky cave PREP-3E cave 'then it happens (at) Lakam Ha' ritual space in the cave of ...' (Palenque Temple of Foliated Cross)

(8) hul-i-ø

$\boldsymbol{t}-\boldsymbol{u} m u k$

arrive-INTR-3SA PREP-3E bury

's/he arrives at his/her grave' (Tonina Zapata Panel)

(9) chum-l-aj-ø

ti-ajaw-lel

k'uk' ajaw

sit-POS-INTR-3SA PREP-lord-ABST quetzal lord

'K'uk' Ajaw sits in kinship (accedes to the throne)' (La Corona Panel 2)

(10) $\quad \boldsymbol{t}$-u-paat 7 Ajaw

PREP-3E-back DATE

'on the back (=after) 7 Ajaw' (Emiliano Zapata Panel)

However, the use of preposition $t i$ / $t a$ is not always obligatory, at least in writing, as can be seen by its frequent omission in front of dates.

The second context where they are absent is illustrated in examples $(7,11$ 13), namely toponyms after stative predicates and intransitive verbs of motion do not require a preposition, no matter whether they follow the predicate immediately or there is another argument between them (Law and Stuart 2017, 163). This might suggest that in Classic Mayan prepositions are, actually, a marginal resource in the inventory of linguistic means to talk about spatial relations.

(11) uht-i-iy-ø

chihk-nahb'

happen-INTR-PST-3SA PLACE.NAME

'it happened (at) Chihknahb (Calakmul)' (Cancuen Panel 1)
(12)
$h u l-i-\varnothing$
?-ha'
Bajlaj Chan Kawiil 
arrive-INTR-3SA PLACE.NAME PERSONAL.NAME

'Bajlaj Chan K'awill arrives (at) ?-Ha' (Dos Pilas)' (Dos Pilas HS 2)

(13) t'ab-ay-ø k'an-tuun-ehb' sak-nik-te'

raise-MP-3SA yellow-stone-step PLACE.NAME

'the limestone step is dedicated (at) Sak Nikte' (La Corona HS2, Bl 9)

\section{Relational nouns}

The infrequent prepositions being so versatile functionally, vague semantically, and non-obligatory in certain contexts, more precise locations may be expressed by relational nouns, which technically are possessed nouns, mostly body parts (Law and Stuart 2017, 163) and introduce all kinds of oblique arguments, including locatives (Aissen, England, and Zavala Maldonado 2017, 5). They may be used in conjunction with a preposition $(14,10)$ or without it $(15-16,4)$ (examples after Law and Stuart 2017: 163-164).

\section{(14) $t$-u-baah}

PREP-3E-head / self

'to him' (Chinikiha Panel 1)

(15) aw-ichnal

2SE-presence

'before you' (Tikal Burial 196, vase K8008)

(16) u-ti'hu'n

3E-lip/edge-paper / book

'the margin of the book (?)' (Tonina M 140)

\section{Positional verbs}

Mayan languages also developed a class of verbs called positionals with meanings related to orientation and form. In Classic Mayan they may be derived with one of the two suffixes -wan (17-18) or -laj $(19,9)$, which seem to be functionally equivalent, they may also be nominalized in certain contexts (20-23) (Law and Stuart 2017, 147). Thus, examples $(17,9)$ show the basic clause structure: the positional verb chum 'to sit' with a positional suffix -wan or -laj followed by a prepositional phrase consisting of preposition $t i$ or $t a$ and a noun denoting a social function with an abstractivizing suffix -lel / -lil, and finally, the subject. Example (18) is particularly interesting because the PP, instead of directly mentioning the office, metonymically uses a characteristic object (crown-like headband) to invoke the whole event of royal accession (conceptual metonymy PART FOR WHOLE, or more specifically A CHARACTERISTIC ATTRIBUTE FOR THE WHOLE ACTION). In examples (19-20) the positional verb features an additional suffix -iy (here interpreted as past) in a subordinate clause where the current events are located in time by mentioning the number of years and/or days elapsed from a chosen base event (here the accession into office). 
(17) chum-laj-ø ta-ajaw-lel

k'inich ahkal mo' naab

sit-POSIT-3SA PREP-ruler-ABST PERSONAL.NAME

'K'inich Ahkal Mo' Naab sits into kingship' (Palenque Panel of 96 Glyphs)

(18) chum-waan- $\varnothing$ ta-huun ahkul mo' nahb

sit-POSIT-3SA PREP-paper PERSONAL.NAME

'he sits with a paper headband Ahkul Mo' Nahb' (Palenque Temple of Inscriptions)

(19) chum-waan-iy-øta-ajaw-lel aj ne ohl mat

sit-POSIT-PST-3SA PREP-ruler-ABST PERSONAL.NAME

'[X years after] Aj Ne Yohl Mat sat into rulership' (Palenque Temple of Inscriptions)

(20) chum-laj-iy-ø

ti-sajal-lil

AjSak Tel

sit-POSIT-PST-3SA PREP-lord-ABST PERSONAL.NAME

'Aj Sak Tel sat into the office of sajal' (Lacanha Lintel 1)

(21) u-chum-tzam saknuk naah

3E-sit-throne

PLACE.NAME

'it (is) throne-seating (at) the White House' (Palenque Panel of 96 Glyphs)

(22) chum-tz'am t-ajaw-lel aj ixim? keey

sit-throne PREP-ruler-ABST PERSONAL.NAME

'it (is) the throne-seating into rulership (of) Aj Ixim? K'eey' (Bonampak Sculpted

Stone 1)

(23)

chan u-chum-tuun

$4 \quad 3$ E-sit-stone

'four are his stone seatings' (Palenque Pakal's sarcophagus lid)

(24) chum kanjalaw

sit MONTH.NAME

'seating of Pop (=0 Pop / 5 Wayeb)'

Examples (21-24) show no verbal morphology, therefore they are interpreted as nominalizations of events (Law and Stuart 2017, 148, 158), more specifically they illustrate the nominalization of a positional verb by noun incorporation. In (21) the small-scale locative (throne) is incorporated and the large-scale locative (building) follows as an oblique argument (without a preposition though). In (22) the syntax mirrors the regular pattern for verbal clauses with the PP referencing the office being taken and the subject concluding the clause. Example (23) is again highly metonymic summarizing the king's achievements by mentioning the number of very important ceremonies performed by him during his lifetime: Pakal the Great celebrated 4 Period Endings, each of which was commemorated by placing a stone. Finally, (24) is a semantic extension into the temporal domain: the cyclical 20-day Haab calendar never mentions the $20^{\text {th }}$ of a month, instead giving this date as $t i^{\text {' }}$ haab 'the edge' of the current month or chum 'the seating' of the next month. Thus, the new month "sits into office" on the last day of the previous one. 
Common positionals include: chum 'to sit', pat 'to form, make, shape, build', $t z$ 'ak 'to complete', $e k$ 'to place, enter, insert', pak 'to invert, turn over, face downwards, fold over', $w a$ ' 'to be erect, set upright, propped up'.

Occasionally, when the figure is part of the ground, its position may be described by a possessive phrase, illustrated in (25). In this case, it is a double possessive describing a part-whole relation between the figure (entrance) and ground (house) and the possession of the ground by a person. Both are coded by ergative prefixes (preconsonantal $u$ - and prevocalic $y$-), the part-whole relation being further elaborated by suffix $-i l$, which changes it into partitive possession (Houston, Robertson, and Stuart 2001, 26-27).

(25) k'al-waan-ø u-paas-il y-otoot ?xook raise-POS-3SA $3 \mathrm{E}_{1}$-opening-INAL $3 \mathrm{E}_{2}$-house ? shark 'she dedicates(?) the entrance of the house of Lady(?) Xook' (Yaxchilan Lintel 23)

\section{Frames of reference}

Frames of reference (FoR) locate the figure in relation to the ground when the two are separate in space (S. C. Levinson and Wilkins 2006b, 541). Languages differ significantly in which frames of reference they employ and in what contexts, and some even seem to impose social restrictions on the use of FoRs. For instance, in Tenejapan Tzeltal (see Figure 8) the most popular FoR is the absolute system based on local geography with terms such as ajk'ol 'uphill' and alan 'downhill' correlating approximately with south and north, and ta jejch 'crossway across the valley ridge' roughly marking the east-west axis; it is used in all contexts if the figure and ground are not adjacent, including tabletop uses (Brown 2006, 263-64; see example (26) below). When they are in closer proximity, it is replaced by the intrinsic system with locatives based body parts and relational nouns, similarly to topological descriptions (ibid.). The use of any ego-centric terms, based on the axes of human body (up/down, front/back, left/right), which could be classified as elements of a relative system is marginal and only used in reference to the front/back axis, never left/right: the concepts exist in the language, e.g. xin k'ab 'left hand' and wa'el k'ab 'right hand' (ibid. 270-271), but they are not used deictically.

Yukatek, on the other hand, exhibits significant gender-based differences in the use of frames of reference. The most common one is the intrinsic system, which is used by all speakers and for some women it is the only FoR they use (see Figure 8 ). The absolute system, used only by adult males, is based on cardinal directions: lak'iin 'east', chik'iin 'west', nohol 'south', xaman 'north' and is used not only to talk about geographical locations, but also in tabletop space (Bohnemeyer and Stolz 2006, 303-4, 308; see (27-28) below). The relative FoR is used by most men, but very few women (ibid. 308), usually using deictic no' $h$ 'right' and ts'iik 
Figure 8: Full, partial and trace frames of reference in two modern Mayan languages (S. C. Levinson and Wilkins 2006a, 568; based on research by Brown and Bohnemeyer \& Stolz)

\begin{tabular}{|c|c|c|c|c|}
\hline & FoR & Type / distinction & Context of use & Other comments \\
\hline \multirow[t]{3}{*}{ Tzeltal } & Absolute & $\begin{array}{l}\text { Uphill/downhill/ } \\
\text { across }\end{array}$ & $\begin{array}{l}\text { All scales and contexts } \\
\text { (though when figure } \\
\text { and ground immediately } \\
\text { adjacent - use intrinsic) }\end{array}$ & $\begin{array}{l}\text { Interpretation can be } \\
\text { global, local or deictic } \\
\text { (usually discernible from } \\
\text { context and activity type) }\end{array}$ \\
\hline & Intrinsic & $\begin{array}{l}\text { Body-part locatives } \\
\text { ( }{ }^{*} \text {.g. at its head) } \\
\text { and relational noun } \\
\text { locatives (e.g. at its } \\
\text { inside) }\end{array}$ & $\begin{array}{l}\text { When figure and ground } \\
\text { are immediately adjacent }\end{array}$ & $\begin{array}{l}\text { Speakers avoid deictic } \\
\text { description alone as } \\
\text { the means for locating } \\
\text { a figure, same resources } \\
\text { used for topology and } \\
\text { intrinsic FoR }\end{array}$ \\
\hline & Relative & Unsystematic & $\begin{array}{l}\text { Highly marginal, only } \\
\text { 'front' / 'back' if at all }\end{array}$ & $\begin{array}{l}\text { No 'left' / 'right' spatial } \\
\text { distinction }\end{array}$ \\
\hline \multirow[t]{4}{*}{ Yukatek } & Intrinsic & Front, back, sides & $\begin{array}{l}\text { Used in all contexts, but } \\
\text { gender-based differences } \\
\text { in use }\end{array}$ & $\begin{array}{l}\text { All speakers use it freely, } \\
\text { for some females this is } \\
\text { their only FoR }\end{array}$ \\
\hline & $\begin{array}{l}\text { Pseudo- } \\
\text { absolute }\end{array}$ & $\begin{array}{l}\text { Highly local ad-hoc } \\
\text { landmarks (e.g. } \\
\text { door) }\end{array}$ & $\begin{array}{l}\text { Object orientation, } \\
\text { direction }\end{array}$ & $\begin{array}{l}\text { Not restricted to any } \\
\text { particular group, but less } \\
\text { systematic }\end{array}$ \\
\hline & Absolute & $\begin{array}{l}\text { Cardinal directions: } \\
\text { north, south, east, } \\
\text { west }\end{array}$ & $\begin{array}{l}\text { Mainly for geographical } \\
\text { scale localizations, may be } \\
\text { used in tabletop space for } \\
\text { motion, more rarely for } \\
\text { location }\end{array}$ & $\begin{array}{l}\text { Used mainly by adult } \\
\text { males }\end{array}$ \\
\hline & Relative & Back/front/right/left & $\begin{array}{l}\text { Common in tabletop } \\
\text { space for localization } \\
\text { (standing) information }\end{array}$ & $\begin{array}{l}\text { Most men have } \\
\text { a command of this FoR, } \\
\text { but only some women } \\
\text { have it }\end{array}$ \\
\hline
\end{tabular}

* Tabletop space refers to small scale space, typically within sight and arms' reach of the speaker, as opposed to geographic-scale space.

'left' to refer to both human body and locations projected away from the body (ibid. 306, see (29)).

$$
\text { ay-ø ta ajkol te limete }
$$

exist-3A PREP uphill ART bottle

'The bottle is to the uphill' (of another bottle, on a table) (Brown 2006, 265)

(27) Tóoh nohol $h$ bin-o'b

straight south PRV go-B.3.PL

'They went straight south' (Bohnemeyer and Stolz 2006, 304)

(28) u ts'o'k hun-péel túun-a', he'l-a' hun-túul pàal

túun pàakat

A.3 end one-CL.IN then-D1 PRSV-DI one-CL.AN child PROG:A.3

look 
toh xaman, nohol $k-u$ páat-al le k’àax

ti'-o'

straight north, south IMPF-A.3 leave $\backslash$ ACAUS-INCDEF bush LOC(B.3.SG)-D2

'the last one, then, here it is, a child, it is looking straight north, the bush remains south of him' (ibid.)

(29) no’h-àn yan-ik te kàax-o’? wáah

ts'ik-an?

right-RES(B.3.SG) EXIST-EF(B.3.SG) LOC:DEF bush-D2 ALT

left-RES(B.3.SG)

'Is he to the right of the bush? Or to the left?' (ibid. 306)

The etymology of the cardinal directions in Yukatek in not entirely clear: the terms for 'east' and 'west' are clearly based on the word k'in 'sun, day', while those for 'north' and 'south' cannot be analysed any further (Bohnemeyer and Stolz 2006, 303). In several other Mayan languages (see Figure 9) 'east' and 'west' also have a very transparent etymology based on the diurnal cycle and they seem to be more prominent than 'north' and 'south' which may be called simply 'sides of the sky' or even have no name at all (Hopkins and Josserand 2011, 3, 8).

Figure 9: Terms for cardinal directions in some contemporary Mayan languages (based on Watanabe 1983: 720-1, 712; Bassie-Sweet 1996: 197)

\begin{tabular}{|c|c|c|c|c|}
\hline Tzotzil & $\begin{array}{l}\text { East } \\
\text { emergent heat } \\
\text { / up }\end{array}$ & $\begin{array}{l}\text { West } \\
\text { waning heat } \\
\text { / down }\end{array}$ & $\begin{array}{l}\text { North } \\
\text { side of the sky }\end{array}$ & $\begin{array}{l}\text { South } \\
\text { side of the sky }\end{array}$ \\
\hline K'iche & $\begin{array}{l}\text { the sun's place of } \\
\text { exit }\end{array}$ & $\begin{array}{l}\text { the sun's place of } \\
\text { entry }\end{array}$ & third side of the sky & $\begin{array}{l}\text { fourth side of the } \\
\text { sky }\end{array}$ \\
\hline Chol & $\begin{array}{l}\text { where the sun } \\
\text { 'sprouts' }\end{array}$ & $\begin{array}{l}\text { where the sun } \\
\text { 'enters' }\end{array}$ & $\begin{array}{l}\text { bad weather } \\
\text { (in } 1 \text { village) }\end{array}$ & $\ldots$ \\
\hline Yukatek & likin 'east' & chikin 'west' & $\begin{array}{l}\text { xaman 'north' or } \\
\text { 'summer' }\end{array}$ & $\begin{array}{l}\text { nohol 'south' or } \\
\text { 'winter' }\end{array}$ \\
\hline Mam & okni 'in' & elni 'out' & jawni 'up' & kubni 'down' \\
\hline
\end{tabular}

This phenomenon is quite common crosslinguistically (see Figure 10): out of 127 languages, the conceptual domain of the Sun is the source for the term for 'east' in 58 of them and for the term for 'west' in 59. The terms for 'north' and 'south' have more varied sources, though the deictic orientation stands out quite conspicuously.

Classic Mayan has a set of four directional terms (see Figure 11) similar to Yukatek with two sets of terms and logograms for 'east and 'west', all of them based on the word and logogram for k'in 'sun', and terms for 'north' and 'south', whose exact reading, meaning and etymology still remain unclear. Stuart (2002) proposed 
Figure 10: The main source domains for cardinal direction terms in 127 languages (Heine 1997, 50, Table 3-7)

Conceptual source

Sun

Deictic orientation

Wind

Landmarks

Other domains

\begin{tabular}{cccc}
\multicolumn{4}{c}{ Cardinal direction } \\
West & East & North & South \\
59 & 58 & 1 & 13 \\
9 & 12 & 12 & 13 \\
-- & -- & 17 & 4 \\
2 & 2 & 7 & 10 \\
-- & 1 & 6 & 3
\end{tabular}

that the term for 'south' may be related to the concept of 'right', which by extension would link 'north' with 'left', and which statistically is fairly probable (see Figure 10). The alternative hypothesis (Bricker 1983; Stross 1991) proposes that the directional terms might not refer to cardinal directions (east, north, west, south) but to the sun's path (east, zenith, west, nadir), so 'north' might stand for the concept of 'zenith' when the sun in the highest in the sky and 'south' for 'nadir' which is zenith's exact opposite (analogously to the European notion of 'midnight' which is by no way marked by any natural phenomenon or event, but must be calculated with a clock). This would be consistent with Mam (see Figure 9), where 'north' is 'up' and 'south' is 'down'. It would also make all four cardinal directions be related to the sun's apparent journey through the sky.
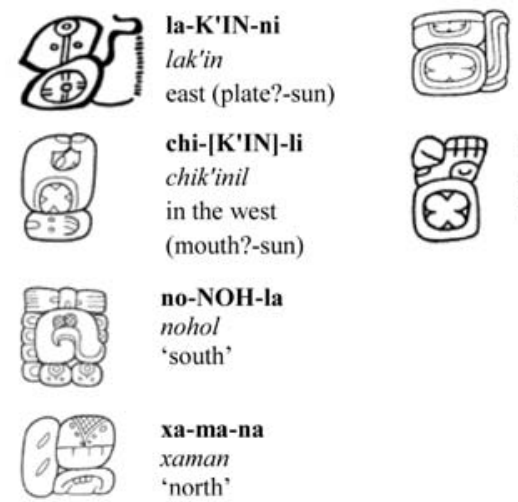

\section{EL-K'IN}

elk'in

east (burn-sun)

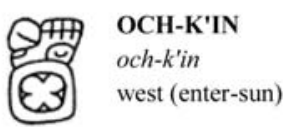

(3) K'IN $\left(k^{\prime} i n\right)$ sun, day

och-k'in

west (enter-sun)

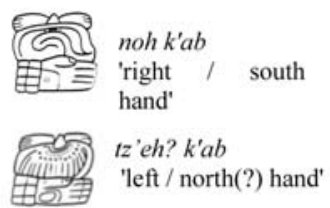

Figure 11: Logograms and terms for cardinal directions in Classic Mayan (drawings J. Montgomery and D. Stuart)

Glyphic terms for cardinal directions appear in titles (30), names of buildings (31)-(32), and a calendrical cycle called 819-Day Count (33)-(35). The $\mathrm{Ka}$ loomte title is not well-understood - the references to cardinal directions may simply mark certain political divisions, but they may as well be geographically based: elk'in kaloomte' was recorded in Lamanai in Belize, nohol - in Copan, xaman in 
Ek' Balam, while ochk'in kaloomte' is thought to be linked to Teotihuacan (Helmke, Guenter, and Wanyerka 2018, 119; Martin and Grube 2008, 141, 144; Wright 2011, 46, 47; Tokovinine 2010,20). In (31) and especially in (32) cardinal directions seem to be part of the names of buildings, so they may indicate their cardinal orientation, but it may also metonymically refer to another politically or culturally significant item (e.g. the region called 'Middle East' in English and 'Near East' in Europe is in fact in Western Asia). Examples (33) and (7) describe events which happened in the chan cheen 'sky-cave', one of the double metonyms which, according to Hull (2012, $108)$, may denote more abstract spatial locations. In particular, Stuart $(2015,25,28)$ argues that they may refer to an architectural or ceremonial feature in the vertical space between the sky and the earth, as opposed to kab cheen 'earth-cave' which marks the central point on the horizontal plane of the lived space. Examples (34-36) illustrate a typical phrasing of a calendrical cycle called 819-Day Count, which "relates to the progression of GII-God K (K'awiil) through four directional quadrants" (Bassie-Sweet and Hopkins 2019, 108; also Newsome 2001, 78; Rice 2015, 274-75; Looper 2019, 141).

(30) ochk'in / elk'in / nohol / xaman kaloomte' western / eastern / southern / northern emperor

(31) u-k'uh-k'aba' y-otoot-xaman

3E-god-name 3E-house-north

(it is) the godly name of the house of north (Palenque Temple of Cross Tablet ) (32) t'ab-ay-ø chik'in mo' naah ta-otoot chah-om raise-MED-3SA west macaw building PREP-house incense-AG 'Ch'ahoom dedicates west macaw building in/as a(?) house' (Palenque Temple of Sun Tablet)

(33) pat-laj-ø u-we' huk chapaht tz'ikin-k'in-ajaw elk'in chan cheen make-POS-3SA 3E-food 7-centipede-eagle-sun-lord east sky-cave 'he makes the food of Huk Chapat Tz'ikin K'in[ich] Ajaw (at) eastern ritual space' (Copan Stela 13)

(34) wa'-jiiy-ø k'awiil-nal elk'in set.upright-PST-3SA K'awiil-place? east

'K'awiil stood up in the east' (Palenque Temple XIX platform south side)

(35) wa'-jiiy-ø elk'in chak ? k'awiil-nal jun-chok

set.upright-PST-3SA east red ? K'awiil-place? 1-young

'K'awiil, the heir, stood up in the east' (Yaxchilan Lintel 30)

(36) wa'-jiiy-ø k'awiil-nal nuk nojol chancheen

set.upright-PST-3SA K'awiil-place? great south sky-cave

'K'awiil stood up in the great southern ritual space' (Palenque Temple of Cross Tablet) 
Generally, the prominence of cardinal directions marked by the diurnal journey of the sun, especially the east where the rising sun begins each day, and relative disregard for the north-south axis (Rice 2007, 81; Hopkins and Josserand 2011, 15), suggests a conceptualization of the world where the ego faces the sunrise, with south on their right and consequently north on the left as the sides of the sky (see Figure 12). This significance of the east may, indeed, be the reason why most Maya (and other native) maps have east on the top of the page (Bassie-Sweet 1996, 197, 229), unlike European maps characteristically oriented north.
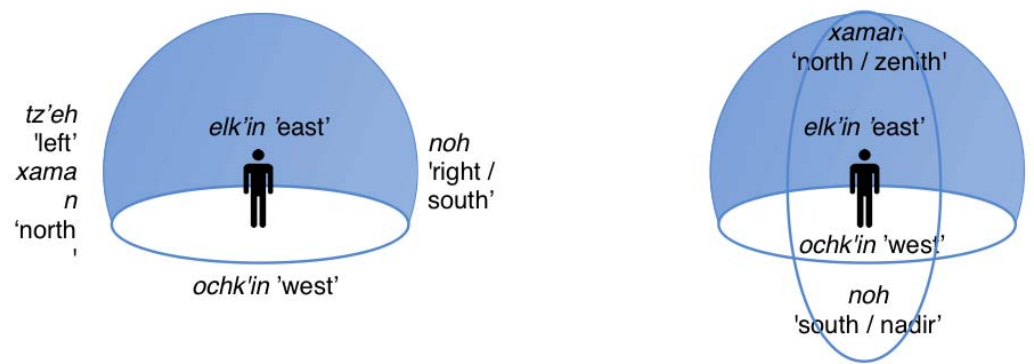

Figure 12: East as the primary cardinal direction in Classic Mayan: horizontal model with south on the right and vertical model with north in the zenith

The extant glyphic texts do not provide examples of the deictic left/right distinction in spatial descriptions, similarly to Tenejapan Tzeltal. Stuart (2002) mentions just a few examples of terms 'right' and 'left' (see 37-39), but none of them has a clearly deictic context which might point to the use of a relative FoR. On the other hand, (40-41) do allow for a spatial interpretation of -ichnal 'before somebody', however, because it is usually used in the third person and occasionally in the second, it belongs to the intrinsic system, since there is no projection of the speaker's axes to locate the figure in relation to the ground. The expression $u$-paat 'on the back of = after' (see 10) so far has only been identified in temporal contexts, however, it most likely was a mapping from the domain of space (conceptual metaphor TIME Is SPACE), though no example can be offered now.

(37)

noh-k'ab tz'eh?-k'ab

'right-hand left-hand (Marcador from Tikal)

(38) u-tz'eh(?)-k'ab k'in-ich

3E-left-hand sun-ADJ

'The Left Hand of the Sun' (Site Q inscription)

(39) noh(?)-k'ab k'in-ich

right-hand sun-ADJ

'Right Hand (of) the Sun' (Tikal MT9)

(40) aw-ichnal $\quad w$-a[j]w-aal

2SE-LOC[front] 1SE-lord-POS 
'before you, my lord' (Tikal Burial 196, vase K8008) (Law et al. 2013, E31)

(41) cham-aw-ø ho'-ko'haw mo'chahk y-ichnal u-k'uh-il yaxha'l chahk

receive-APAS-3SA 5-helmet PERS.NAME 3E-LOC[front] 3E-god-INAL first rain NAME

'Mo' Chahk receives 5 helmets before the God of Yax Ha'l Chahk' (Piedras Negras Panel 2)

\section{Motion}

Generally speaking, motion involves spatial change, change involves time, and dynamic change over time is typically coded in language by verbs (S. C. Levinson and Wilkins 2006c, 17). Thus, verbs of motion describe the figure's change of location in relation to the ground, however languages differ in how they package the notions of path and manner, source and goal into the verb or into other arguments of the clause.

Classic Maya texts feature several intransitive verbs of motion (31-36). Similarly to positionals, they do not require a preposition or relational noun before the locative (31-34), which may immediately follow the predicate (Law and Stuart $2017,134)$ and they may incorporate an argument (destination or subject (ibid. 158); (35-36) show destination-incorporation) into the predicate.

(42) $\quad$ tal-i- $\varnothing$ wi'-te'-naah k'inich yax k'uk' mo'

arrive.here-INTR-3SA PLACE.NAME PERSONAL.NAME

K'inich Yax K'uk' Mo' arrives here (at) Wi Te' Naah (Copan Altar Q)

(43) $i$ hul-i-ø mutul

then return.here-INTR-3SA PLACE.NAME

then he returns here (at) Tikal (Tikal Temple IV Panel 3)

(44) bixan-ø

chi'k nahb

go.away-3SA PLACE.NAME

he travels (to/from?) Calakmul (La Corona Panel 1)

[date] lok'-oy-ø usiij witz [date] sut-uy-ø exit-DER-3SA PLACE.NAME return-DER-3SA

'he leaves Usiij Witz and returns to his place of origin' (Bonampak Sculpted Stone 5)

(46) och.ha'-aj-ø chak-tok-ichiaak

enter.water-DER-3SA PERSONAL.NAME

'Chak Tok Ich'aak water-enters (=dies)' (Tikal Stela 31)

(47) $i \quad$ och-bih-aj-ø

then enter-road-DER-3SA

'then s/he road-enters (=dies)' (Palenque Palace Tablet)

(48) och k'ak' ta-y-otot

'the fire enters into his house' (Palenque Tablet of 96 Glyphs) 
(49) och-i k'ak' t-u-muk-nal-il K'an Mo'Balam

'fire enters into the tomb of K'an Mo' Balam' (Seibal Tablet 5) (Stuart 1998, 417-18)

However, the exact meanings of the motion verbs in Classic Mayan are still not entirely clear. First, there are no dictionaries or grammars surviving from the Classic Period (possibly there were none). Secondly, guessing their meanings from context is a challenge because all the semantic content seems to be packaged into the verb - no satellites, prepositional phrases, relational nouns or deictic expressions to guide and support the interpretation of motion events.

On the other hand, research on modern Mayan languages shows that in this linguistic family the semantics of motion verbs may be very elaborate and particular. Figure 13 compares the very general and schematic meanings produced by etymological reconstruction of the Mayan linguistic family going back as far as Proto-Mayan spoken around 2200 BCE (Kaufman 2017, 66) with rich and detailed meanings in two modern Mayan languages, for which an extensive study of the spatial language was conducted. Thus, in Tenejapan Tzeltal motion verbs tal, jul and ko (see ex. 37-39) are deictically anchored, referencing motion to and away from 'here' where the speaker is (Brown 2006, 254), while in Yukatek tàal and $u^{\prime} l$ are deictic, but k'uch is not, however they all take the goal of motion as the ground

Figure 13: Motion verbs in Proto-Mayan, Classic Mayan and other Mayan languages

Etymological reconstruction for ProtoMayan, Classic Mayan \& other Mayan languages (Kaufman and Justeson 2003; Kaufman 2017) tyaal in PM 'to come / venir'

huul 'llegar acá; to arrive here' in ProtoMayan and others;

kot / k'och 'llegar allá / to arrive elsewhere' in several languages;

sut 'to go back, return; volver' in PM and others;

lok' 'salir, escapar' in some languages

'ook / och 'entrar / to enter' in PM and others

bixan possibly conflation of beeh 'camino / road' + xan 'andar, caminar' in PM (see also Kettunen and Helmke 2019, 89)
Modern Tenejapan

Tzeltal (Brown 2006, 251-56)

tal 'to come, to arrive here' (deictic), see ex. (31, $35,36)$

jul 'to arrive here, to return here' (deictic), see (32)

$k o(t)$ 'to arrive there' (deictic), see (33)

sujt 'to return' (to a point of origin), see $(31,34)$

lok' 'to exit' (a bounded region), see $(36,37)$

och 'to enter' (a bounded region), see (35)

$b a$ 'to go' (deictic or unspecified), see $(33,34$, 37,38 )
Modern Yukatek Maya

(Bohnemeyer and Stolz 2006, 300, Table 8.6)

tàal 'come', ground: goal, deictic only

u'l 'return', ground: goal, deictic only

k'uch 'arrive', ground: goal, lexical

sùut 'return, ground: goal, lexical

hook 'exit', ground: source, lexical

òo 'enter', ground: goal, lexical

bin 'go', ground: source, deictic or anaphoric

Tenejapan Tzeltal (examples after Brown 2006, 251-56) 
(Bohnemeyer and Stolz 2006, 300). Example (53) represents a point-oriented motion verb: "sujt adopts the reference point as a goal and presupposes that [...] the current goal represents a 'return", e.g. to the place of origin (Brown 2006, 256); in Yukatek the ground is also the goal, but it is not deictic, thus the point of departure may be elsewhere (Bohnemeyer and Stolz 2006, 300). Verbs lok' and och in (4143) illustrate enclosure-oriented motion to or from a bounded region which may be either physically bounded or abstract (Brown 2006, 256), in Yukatek they are also non-deictic, and hook 'exit' is followed by the source, while ook 'enter' by the goal (Bohnemeyer and Stolz 2006, 300). In Tzeltal ba 'to go' (44) may be deictic or unspecified acquiring the deictic interpretation from context (Brown 2006, 254), while in Yukatek bin 'to go' may be deictic or anaphoric with the ground argument representing the source (Bohnemeyer and Stolz 2006, 300). In Tzeltal, motion verbs may be further specified by the use of directionals (see 37, 41-43), that is deverbal directional particles formed from a root motion verb and suffix $\mathrm{Vl}$ (vowel and /1/), the most common being tal 'coming' and bel 'going' (Brown 2006, 252).

(50) ya $x$-tal kik'-at sujtel pajel

ICP ASP-come 1E-fetch-2A returnDIR tomorrow

'I'll come fetch you back tomorrow'
(51) $y a \quad x$-jul
$y$-al-be- $t$
pajel

ICP ASP-AUX(arrive.here) 3E-tell-DIT-2A tomorrow

'he'll arrive to tell you tomorrow'

(52) $\varnothing \quad \underline{b a-o n} t z^{\prime} i n, \varnothing \quad \underline{k o}-o n$ tey $a$,

CMP go-1A PT, CMP arrive-1A there DEIC,

$\emptyset \quad \underline{k} 0$ j-ḱopon-ø te j-mamal alib-e

CMP arrive 3E-talk.with-3A ART father.in.law-CL

'so I'd go, I'd arrive there, arrive to talk with my father-in-law'

(53) $\varnothing \quad$ bajt- $\varnothing$ tz'in te yan antz-e, $\varnothing \quad$ sujt- $\varnothing$

CMP go-3S PT ART other woman-CL. CMP return-3A

$x a b$ t-u'un $t z^{\prime} i$

again 3E-REL PT

'the other woman went away, she returned (to her natal home) then'

(54) ja' jich a och-ø tal te j-chamel-e

it.is thus CMP enter-3A comeDIR ART 1E-sickness-CL

'that's how my sickness entered into me'

(55) lok'-an tal

exit-IMP comeDIR

'Come out (of the house, to where I am)'

(56) lok'-an bel

exit-IMP goDIR

'go out (of the house where I am) 
(57) $y a \quad x-\underline{b a}$

$k$-il-ø $\quad k$-ala

wakax

ICP ASP-AUX(go) 1E-see-3A 1E-DIM bull

'I'm going to see my bull'

Thus, based on the analyses of examples (31-36), (37-44) and Figure 13, I would like to propose the following descriptions for the motion verbs in Classic Mayan (see Figure 14). Of course, polysemy being a norm for any linguistic unit, this does not exhaust all the possible meanings of the verbs, and is only meant as a starting point for further research.

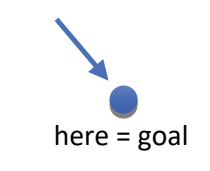

tal 'come here from elsewhere' (source irrelevant)

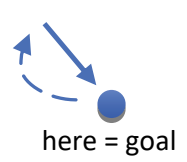

hul 'return here from elsewhere where one went to earlier'

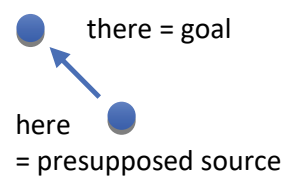

$k$ 'ot 'arrive there' (source not verbalized but understood)

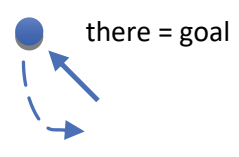

sut 'return to point of origin' (source irrelevant)

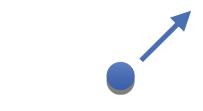

here $=$ source

bixan 'road-walk' (deictic or anaphoric, possibly source as ground argument)

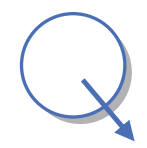

lok' 'exit a bounded region $=$ source' (non-deictic)

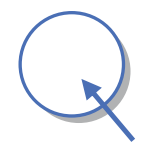

och 'enter a bounded region $=$ goal' (non-deictic)

Figure 14: Suggested semantic fields of verbs of motion in Classic Mayan

If the above hypothesis is correct, then in (31) K'inich Yax K'uk' Mo' comes here to Wi' Te' Naah from elsewhere and later huli oxwitik 'returns here to Oxwitik from wherever he went to earlier. In this scenario, both Wi'Te'Naah and Oxwitik would be located in Copan where presumably Altar Q was produced. The other possibility is that in Classic Mayan tal meant 'to go there', then the former could be located elsewhere (Tikal? Teotihuacan? (see Martin and Grube 2008, 192-93)), which would provide a fitting context for the later huli oxwitik event, similarly to (43) where the protagonist returns to Tikal after a war. The verb $h u l$ is also used in the Lunar Series, part of the calendrical information pertaining to the return of the moon, after the dark moon (when it was invisible). In (44) the older brother travels - but it is difficult to determine from context whether he travels to or from Calakmul, however, if in this case the source is indeed the ground argument, then he would be travelling from Calakmul to La Corona, where this monument comes from. Verbs in (45) most likely refer to Yaxuun Bahlam, who after 
overseeing the accession of a Bonampak ruler, leaves Bonampak and returns to his home town of Yaxchilan. The death expressions in $(35,36)$, being metaphoric, suggest that either bodies of water and roads were conceptualized as bounded regions or that death was perceived as entering a physical space, which is consistent with the conceptual metaphor STATES ARE LOCATIONS (being dead is being in a confined space).

Figure 15 summarizes Brown's and Bohnemeyer and Stolz's research on two modern Mayan languages. Both were rather problematic to classify, but generally they exhibit more characteristics of a verb-framed language, though Tzeltal features satellite-like directionals and Yukatek requires redefining the notion of 'path' as a punctual change of location to be counted as such. Both languages have a strict grammatical rule allowing only one reference location per clause, and its interpretation as 'source' or 'goal' depends on the verb semantics or context or (in Tzeltal) directional, while ground-denoting arguments do not contribute any 'path' information. Henderson $(2016,556-57)$ extends this conclusion to other Mayan languages, all of which seem to be "radically verb-framing", as they lexicalize all path information in the verb and have no prepositions encoding path, although some have directionals - verbal clitics that complement the verb's path information.

Figure 15: Summary of motion coding properties in Tzeltal and Yukatek (S. C. Levinson and Wilkins 2006b, 529; based on research by Brown and Bohnemeyer / Stolz)

\begin{tabular}{|c|c|c|c|}
\hline & $\begin{array}{l}\text { Verb-framed } \\
\text { satellite-framed }\end{array}$ & $\begin{array}{l}\text { Manner-of-motion } \\
\text { resources }\end{array}$ & Source/goal ground marking \\
\hline Tzeltal & $\begin{array}{l}\text { Verb-framed (though } \\
\text { directionals are } \\
\text { satellite-like in } \\
\text { contributing path } \\
\text { info) }\end{array}$ & $\begin{array}{l}\text { Few manner-of- } \\
\text { motion verbs. } \\
\text { Indicated by } \\
\text { derivation. }\end{array}$ & $\begin{array}{l}\text { One general preposition marking } \\
\text { oblique phrases. } \\
\text { Only one reference location (source or } \\
\text { goal) expressed by clause. } \\
\text { Interpretation as 'source' or 'goal' from } \\
\text { verb and/or directional and/or context. }\end{array}$ \\
\hline Yukatek & $\begin{array}{l}\text { Problematic, possibly } \\
\text { verb-framed but } \\
\text { requires redefining } \\
\text { the notion of 'path'. } \\
\text { 'Path' verbs do } \\
\text { not entail durative } \\
\text { locomotion along } \\
\text { an extended spatial } \\
\text { trajectory, but only } \\
\text { punctual change of } \\
\text { location. }\end{array}$ & $\begin{array}{l}\text { Lexicalized mainly } \\
\text { in active intransitive } \\
\text { verbs, which by } \\
\text { themselves do not } \\
\text { entail change of } \\
\text { location. }\end{array}$ & $\begin{array}{l}\text { Grounds of motion events expressed by } \\
\text { adverbials. } \\
\text { Ground-denoting adjuncts do not } \\
\text { reflect 'path' of motion event. } \\
\text { There is no formal reflex of the } \\
\text { 'source'/'goal' distinction. } \\
\text { General prepositions, relational nouns, } \\
\text { toponyms, etc. only get interpreted } \\
\text { as 'source' or 'goal' based on verb } \\
\text { semantics. } \\
\text { One ground-denoting adjunct per } \\
\text { clause. }\end{array}$ \\
\hline
\end{tabular}




\section{Conclusions}

The linguistic treatment of the spatial domain in Classic Mayan is by necessity not as exhaustive as in any modern language, as we are limited to a rather fragmentary and incomplete corpus of extant written texts. However, certain patterns emerge in how the spatial sub-domains are coded in the sample of language analysed in this paper, thus making it possible to draw certain conclusions about the underlying conceptualizations of spatial distinctions, hopefully, adding to our understanding of the nature of human spatial cognition.

The topological sub-domain, where the figure and ground are in contiguity or close proximity, employs:

- $\quad$ prepositions for general static locations, semantically general and nonobligatory in certain contexts, e.g. with toponyms after stative predicates (see examples (6-10) for ti, (1-3) tahn, (4) tahnil, $(2,6,7,11-13)$ for lack of preposition),

- relational nouns which cover the relationship between the figure and ground in more detail (14-16),

- $\quad$ positional verbs - contrastive spatially descriptive predicates (17-24).

In the case of a sample so scant, it is problematic to speculate about canonical and non-stereotypical figure-ground relations in the coding of spatial scenes, especially basic locative constructions. "Figures that are cultural artefacts used to perform actions with typical results are likely to evoke [a] competing class of constructions", e.g. stative resultative constructions: The stamp has been stuck on a letter, or a non-locative verb: The man is wearing a hat (S. C. Levinson and Wilkins 2006b, $516,518)$.

In spatial situations where the figure and ground are not in close proximity, frames of reference come into play. The simplest (first acquired by children) is the intrinsic system, which describes the figure-ground relation in reference to the geometry of the ground without referring to external factors (projection of speaker's bodily axes or abstract system of directions). It is, thus, very close to the topological description and in some languages those two may use the same linguistic resources, making the borderline between "close proximity" of a topological description and "separation in space" of an intrinsic FoR very fluid indeed. The semantically vague prepositions of Classic Mayan, or even the more precise relational nouns, are an excellent example of this ambiguity. Even in English, for instance, if The ladder is at the back of the house, there is no way of knowing if it is propped against the back of the house (topology) or standing somewhere further away (intrinsic FoR).

The available linguistic material does not provide any conclusive evidence for the use of a relative system that involves mapping the speaker's coordinate system (their front/ back/ left/ right) onto the ground object to locate the figure. The existing contexts for expressions tupaat 'on the back of, after,' yichnal 'in front of, before', 
tahnil 'in front of' seem to be intrinsic (object-focussed) uses of the coordination system or topological descriptions of a static scene. However, Classic Mayan does seem to employ a fully-developed and abstract absolute frame of reference based on cardinal directions marked by the apparent movement of the sun in the sky.

In the sub-domain of motion, Classic Mayan is likely a verb-framed language, that is all the path information is packaged in the verb, while toponyms and other locative expressions get the interpretation as 'source' or 'goal' based on the semantics of the verb and/or context. Moreover, because it seems to conform to the one-locative-per-clause rule, like Yukatek or Tzeltal, it may also conceptualize motion not as durative translocation through a series of points in space, but as a non-durative change of location or change of locative relation without trajectory (S. C. Levinson and Wilkins 2006b, 531-32): the figure leaves the source or arrives at the goal, or disappears here and reappears there, and what happens in-between is simply irrelevant and immaterial. The sources and goals are usually coded with zero-marking (no adposition or case); in certain contexts the generic preposition is used, however, this still does not seem to distinguish between the source and goal.

\section{References}

Aissen, Judith, Nora C. England, and Roberto Zavala Maldonado

2017 'Introduction. In The Mayan Languages, edited by Judith Aissen, Nora C. England,andRoberto Zavala Maldonado, 1-15. Routledge Language Family Series. London: Routlegde. https://www.routledge. com/The-Mayan-Languages/Aissen-England Zavala-Maldonado/p/ book/9780415738026.

Bassie-Sweet, Karen

1996 At the Edge of the World: Caves and Late Classic Maya World View. Norman: University of Oklahoma Press.

Bassie-Sweet, Karen, and Nicholas A. Hopkins

2019 Maya Narrative Arts. 1 edition. Louisville: University Press of Colorado.

Bohnemeyer, Jürgen, and Christel Stolz

2006 'Spatial Reference in Yukatek Maya: A Survey'. In Grammars of Space: Explorations in Cognitive Diversity, edited by Stephen C. Levinson and David Wilkins, 230-72. Language, Culture, and Cognition 6. Cambridge, UK ; New York: Cambridge University Press.

Bricker, Victoria R

1983 'Directional Glyphs in Maya Inscriptions and Codices'. American Antiquity 48 (2): 347-53. https://doi.org/10.2307/280455.

Bricker, Victoria R., and Olanike O. Orie

2014 Schwa in the Modern Yucatecan Languages and Orthographic Evidence of Its Presence in Colonial Yucatecan Maya, Colonial Chontal, 
Brown, Penelope

and Precolumbian Maya Hieroglyphic Texts. International Journal of American Linguistics 80: 175-207.

2006 'A Sketch of the Grammar of Space in Tzeltal'. In Grammars of Space: Explorations in Cognitive Diversity, edited by Stephen C. Levinson and David Wilkins, 230-72. Language, Culture, and Cognition 6. Cambridge, UK ; New York: Cambridge University Press.

Evans, Vyvyan

2007 A Glossary of Cognitive Linguistics. Edinburgh: Edinburgh University Heine, Bernd Press. http://www.vyvevans.net/GLOSSARY.pdf.

1997 Cognitive Foundations of Grammar. New York: Oxford University Press. http://site.ebrary.com/id/10142240.

Helmke, Christophe, Stanley P. Guenter, and Phillip J. Wanyerka

2018 'Kings of the East: Altun Ha and the Water Scroll Emblem Glyph'. Ancient Mesoamerica 29 (1): 113-35. https://doi.org/10.1017/ S0956536117000256.

Henderson, Robert

2016 'Mayan Semantics'. Language and Linguistics Compass 10 (10): 551-88. https://doi.org/10.1111/lnc3.12187.

Hopkins, Nicholas A., and J. Kathryn Josserand

2011 'Directions and Partitions in Maya World View'. FAMSI Foundation for the Advancement of Mesoamerican Studies, Inc. http://www.famsi. org/research/hopkins/DirectionalPartitions.pdf.

Houston, Stephen D, John S. Robertson, and David Stuart

2001 'Quality and Quantity in Glyphic Nouns and Adjectives'. Research Reports on Ancient Maya Writing 47. Washington, D.C: Center for Maya Research.

Hull, Kerry

2012 'Poetic Tenacity: A Diachronic Study of Kennings in Mayan Languages'. In Parallel Worlds: Genre, Discourse, and Poetics in Contemporary, Colonial, and Classic Maya Literature, edited by Kerry Hull and Michael D. Carasco. University Press of Colorado. https://www.academia. edu/7013954/Poetic_Tenacity_A_Diachronic_Study_of_Kennings_ in_Mayan_Languages.

Kaufman, Terrence

2017 'Aspects of the Lexicon of Proto-Mayan and Its Earliest Descendants'. In The Mayan Languages, edited by Judith Aissen, Nora C. England, and Roberto Zavala Maldonado, 62-111. London: Routlegde. https:// www.routledge.com/The-Mayan-Languages/Aissen-England-ZavalaMaldonado/p/book/9780415738026. 
Kaufman, Terrence, and John Justeson

2003 A Preliminary Mayan Etymological Dictionary. FAMSI. http://www. famsi.org/reports/01051/pmed.pdf.

Kettunen, Harri, and Christophe Helmke

2019 Introduction to Maya Hieroglyphs. 16th ed. Wayeb. https://www.wayeb. org/wp-content/uploads/2019/04/wh2019english.pdf.

Law, Danny, Stephen Houston, Nicholas Carter, Marc Zender, and David Stuart

2013 'Reading in Context: The Interpretation of Personal Reference in Ancient Maya Hieroglyphic Texts. Journal of Linguistic Anthropology 23 (2): E23-47.

Law, Danny, and David Stuart

2017 'Classic Mayan: An Overview of Language in Ancient Hieroglyphic Script'. In The Mayan Languages, edited by Judith Aissen, Nora C. England, and Roberto Zavala Maldonado, 128-72. London: Routlegde. https://www.routledge.com/The-Mayan-Languages/Aissen-EnglandZavala-Maldonado/p/book/9780415738026.

Levinson, Stephen

2003 Space in Language and Cognition: Explorations in Cognitive Diversity'. Space in Language and Cognition: Explorations in Cognitive Diversity Vol. 5 (January). https://doi.org/10.1017/CBO9780511613609.

Levinson, Stephen C., and David Wilkins, eds

2006a Grammars of Space: Explorations in Cognitive Diversity. Language, Culture, and Cognition 6. Cambridge, UK ; New York: Cambridge University Press.

Levinson, Stephen C, and David P. Wilkins

2006b 'Patterns in the Data: Towards a Semantic Typology of Spatial Description' In Grammars of Space: Explorations in Cognitive Diversity, edited by Stephen C. Levinson and David Wilkins, 512-52. Language, Culture, and Cognition 6. Cambridge, UK; New York: Cambridge University Press.

2006c 'The Background to the Study of the Language of Space'. In Grammars of Space: Explorations in Cognitive Diversity, edited by Stephen C. Levinson and David Wilkins, 1-23. Language, Culture, and Cognition 6. Cambridge, UK ; New York: Cambridge University Press.

Looper, Matthew G.

2019 The Beast Between: Deer Imagery in Ancient Maya Art. University of Texas Press.

López Oliva, Macarena Soledad

2012 El Uso de las preposiciones ta y ti en los códices jeroglíficos Mayas del Período Posclásico (MA thesis). Universidad Complutense de Madrid. 
Macri, Martha J.

1991 Prepositions and complementizers in the Classic Period inscriptions. In Sixth Palenque Round Table, 1986, pp. 266-272. Virginia Fields, ed. (Merle Greene Robertson, series editor). University of Oklahoma Press, Norman.

Martin, Simon, and Nikolai Grube

2008 Chronicle of the Maya Kings and Queens: Deciphering The Dynasties of the Ancient Maya. 2nd ed. edition. London: Thames \& Hudson.

Newsome, Elizabeth A.

2001 Trees of Paradise and Pillars of the World: The Serial Stelae Cycle of '18Rabbit-God K', King of Copan. University of Texas Press.

Rice, Prudence M.

2007 Maya Calendar Origins: Monuments, Mythistory, and the Materialization of Time. Austin: University of Texas Press.

2015 "The "Las Bocas Mosaic" and Mesoamerican Astro-Calendrics: "Calculator" or Hoax?' In Cosmology, Calendars, and Horizon-Based Astronomy in Ancient Mesoamerica, edited by Anne S. Dowd and Susan Milbrath, 265-83. University Press of Colorado. https://doi. org/10.5876/9781607323792.c011.

Stross, Brian

1991 'Classic Maya Directional Glyphs'. Journal of Linguistic Anthropology 1 (1): 97-114. https://doi.org/10.1525/jlin.1991.1.1.97.

Stuart, David 1998

'The Fire Enters His House": Architecture and Ritual in Classic Maya Texts. In Function and Meaning in Classic Maya Architecture, edited by Stephen D Houston. Washington, D.C: Dumbarton Oaks Research Library and Collection. http://www.doaks.org/resources/publications/ doaks-online-publications/classicmaya/maya010.pdf.

2002 'Glyphs for "Right" and "Left"?' Mesoweb. http://www.mesoweb.com/ stuart/notes/RightLeft.pdf.

2015 'Earth-Caves and Sky-Caves: Intersections of Landscape, Territory and Cosmology among the Ancient Maya'. Lecture, University of Texas at Austin, December. https://www.academia.edu/35070038/Earth-caves_ and_Sky-caves_Intersections_of_Landscape_Territory_and_Cosmology_among_the_Ancient_Maya.

Sweetser, Eve, and A.R. Gaby

2017 'Linguistic Patterns of Space and Time Vocabulary'. In The Cambridge Handbook of Cognitive Linguistics, edited by Barbara Dancygier, 62534. Cambridge Handbooks in Language and Linguistics. Cambridge UK: Cambridge University Press. 
Talmy, Leonard

1985 'Lexicalization Patterns: Semantic Structure in Lexical Forms'. In Language Typology and Syntactic Description, edited by T. Shopen, 36-149. Cambridge: Cambridge University Press.

2000 Toward a Cognitive Semantics. Language, Speech, and Communication. Cambridge, Mass: MIT Press.

Tokovinine, Alexandre

2010 'The Western Sun: An Unusual Tzolk'in - Haab Correlation in Classic Maya Inscriptions'. PARI Journal 11 (2): 17-21.

Tyler, Andrea, and Vyvyan Evans

2007 The Semantics of English Prepositions: Spatial Scenes, Embodied Meaning, and Cognition. Reprint edition. Cambridge u.a: Cambridge UniWright, Mark versity Press.

2011 'A Study of Classic Maya Rulership'. PhD Dissertatation, Riverside: University of California. 